\title{
The Expression of Chromogranin A, Syanptophysin and Ki67 in Detecting Neuroendocrine Neoplasma at High Grade Colorectal Adenocarcinoma
}

\author{
W. A. Gusti Deasy ${ }^{1}$, M. Husni Cangara ${ }^{1}$, Andi Alfian Zainuddin² ${ }^{2}$ Djumadi Achmad ${ }^{1}$, Syarifuddin Wahid ${ }^{1}$, Upik A. Miskad $^{1 *}$ (D) \\ ${ }^{1}$ Department of Anatomical Pathology, Faculty of Medicine, Universitas Hasanuddin, Makassar, Indonesia; ${ }^{2}$ Department of \\ Public Health and Community, Faculty of Medicine, Universitas Hasanuddin, Makassar, Indonesia
}

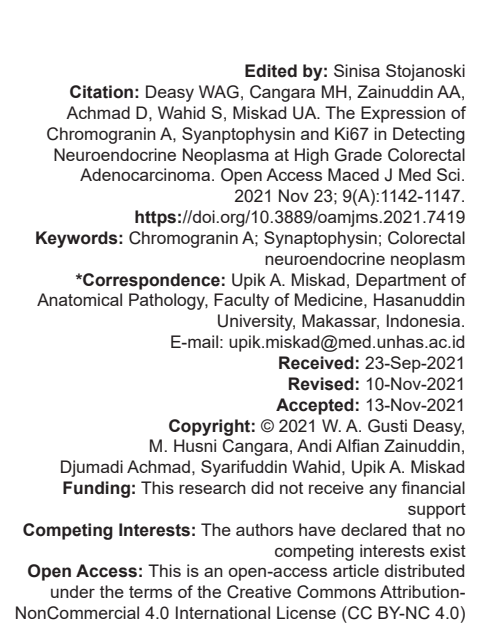

\begin{abstract}
BACKGROUND: Neuroendocrine neoplasm (NEN) is an epithelial cell neoplasm that can give a histopathologica appearance resembling high-grade colorectal adenocarcinoma. Immunohistochemical assays with specific neuroendocrine markers of chromogranin $\mathrm{A}$ and synaptophysin are required to establish a definite diagnosis of NEN

AIM: This study aimed to determine whether there was an expression of chromogranin A, synaptophysin and Ki67 which indicated the presence of neuroendocrine neoplasms in samples that have been diagnosed as high-grade colorectal adenocarcinoma.

MATERIALS AND METHODS: A study of the expression of chromogranin A, synaptophysin and Ki67 in paraffin blocks was carried out as a result of biopsy and tissue surgery of 70 samples of colorectal tumor specimens diagnosed with colorectal adenocarcinoma. Descriptive analyses were used to assess the study results of the amount of chromogranin A, synaptophysin, and sample characteristics.

RESULTS: We discovered that eight (8) samples (11.4\%) were NEN from 70 previously diagnosed samples as high-grade colorectal adenocarcinoma using immunohistochemical assay with neuroendocrine markers, namely chromogranin A and synaptophysin.

CONCLUSION: The final diagnosis obtained from 8 samples diagnosed as NEN were Neuroendocrine tumor (NET) $\mathrm{G} 1, \mathrm{G} 2$, and $\mathrm{G} 3$, respectively $1.4 \%$ and LCNEC $7.1 \%$ based on the specific neuroendocrine markers of chromogranin A, synaptophysin and Ki67.
\end{abstract}

\section{Introduction}

Colorectal cancer is one of the most common cancers globally and one of the top three leading causes of cancer-related death in many Asian countries [1] Neuroendocrine neoplasm (NEN) is a type of colorectal cancer found in the gastrointestinal tract and consists of cell proliferation that has characteristics like nerve cells but produces amine and/or peptide hormone products and is functional or non-functional [2], [3], [4]. The incidence of rectal and colonic NEN in the US is 1.2 and 0.2 new cases per 100,000 person-years, respectively [5].

More than $90 \%$ of colorectal carcinomas are adenocarcinomas which is one of the differential diagnoses for NEN [6]. Several high-grade colorectal adenocarcinomas showed neuroendocrine cell differentiation in various tumor parts [7]. There were also some cases of Large Cell Neuroendocrine Carcinoma (LCNEC), which were difficult to distinguish from highgrade adenocarcinoma with a solid growth pattern. It is challenging to diagnose neuroendocrine cell differentiation or to differentiate LCNEC from high-grade colorectal adenocarcinoma routinely with HematoxylinEosin (HE) staining, so special staining is required [8].

The immunohistochemical examination is essential for establishing a definite diagnosis of NEN, prognostic assessment, and therapy [9]. Currently, various neuroendocrine markers have been widely used to identify neurosecretory granules found in the cytoplasm of neuroendocrine tumor cells such as chromogranin A, synaptophysin, neuron-specific enolase (NSE) and Ki67 to determine tumor grade. Chromogranin A ( CgA) is an acidic glycoprotein that is exclusively expressed on the secretory dense nuclear granules in normal cells or neuroendocrine cell, and is the most specific antibody detecting neuroendocrine cell differentiation [10], [11]. Synaptophysin is an integral membrane glycoprotein present in presynaptic neuronal vesicles [10], which is a very effective tumor marker for identifying neuroendocrine cells and has high sensitivity but lower specificity compared to Chromogranin A antibodies [5].

The diagnosis of NEN requires a comprehensive assessment between morphological and cytomorphological assessment through HE staining 
and immunohistochemistry. Patients diagnosed with NEN will be explicitly treated that is different from the regimen for other gastrointestinal malignancies such as adenocarcinoma [12]. Based on this, the researchers intended to conduct a study on the expression of chromogranin A and synaptophysin in detecting neuroendocrine neoplasms in high-grade colorectal adenocarcinoma. This research has never been done in Makassar before.

\section{Materials and Methods}

This study was a descriptive study, in which 70 samples of high-grade colorectal adenocarcinoma were collected from the Anatomical Pathology Laboratory, Universitas Hasnuddin Hospital, Makassar, RSUP DR. Wahidin Sudirohusodo, and Makassar Pathology Diagnostic Center for the period of January 2015 to December2019. They were diagnosed histopathologically based on H\&E stain. The collected samples that met the inclusion criteria were paraffin block/slide originating from colon and/or rectum tissue taken by biopsy or resection and diagnosed histopathologically with an H\&E stain as high-grade colorectal adenocarcinoma then re-evaluated by two pathologists and investigators for a definite diagnosis of a high-grade colorectal adenocarcinoma and assessed the growth pattern and cytomorphology of the tumor cells. This research has been approved by the Ethics Committee of the Faculty of Medicine, Universitas Hasanuddin.

\section{Examination of hematoxylin and eosin}

HE staining method was modified from standardized hematoxylin and eosin method for tissue staining [13]. The collected paraffinized tissue blocks were cut with a $4 \mu \mathrm{m}$ thick microtome, put into a water bath, and placed on a polysilane slide. The tissue slides were deparaffinized with xylol for 5 minutes and rehydrated with $95 \%$ and $70 \%$ alcohol. The next step was to rinse the slides with tap water before soaked them in the Hematoxylyn Mayer solution. The slides must be rinsed again until the slides turn blue. The slides were gradually immersed with 1\% Eosin solution for 5 minutes, in $70 \%$ and $95 \%$ alcohol for 2-5 minutes. Then, the slides were soaked in carbol xylol and xylene solution for 2-5 minutes. Finally, the slides were drained and covered with mounting agents and cover glass.

\section{Examination of IHC expression of} chromogranin A, synaptophysin and Ki67

Immunohistochemical staining (IHC) was performed to observe and determine the expression of chromogranin A, synaptophysin and Ki67. It was evaluated using paraffin blocks containing tumor tissue that had been cut and placed on glass slides. The tissue sections on glass slides were deparaffinized with xylene and hydrated in graded diluted alcohol. The immunohistochemical assay was done by using the standard avidin-biotinperoxidase complex (ABC) method [14]. The unstained slides were incubated with peroxidation-1 for 5 mins at room temperature, followed by the $\mathrm{ABC}$ procedure. The immunohistochemical assay used rabbit monoclonal antibody chromogranin A (Medyasis, clone MD87R) with 1:50 dilution, synaptophysin (Medyasis, clone EP158, RTU) and anti-Ki67 (Synthetic, clone Polyclonal, RTU). The results of the immunohistochemical examination were evaluated using a light microscope with a doubleblind method by two pathologists and researchers that were judged positive if the cytoplasm of tumor cells stains brown for chromogranin $A$ and synaptophysin staining and brown in the nucleus of tumor cells for Ki67 staining. They were reassessment of growth patterns and cytomorphology of tumor cells.

\section{Statistical analysis}

From the results obtained, all data were recorded and grouped based on the purpose and type of data to be analyzed using univariate analysis. Univariate analysis was performed to describe the characteristics of the primary data in the form of $\mathrm{IHC}$ profile data of chromogranin A, synaptophysin and Ki67.

\section{Results}

\section{Samples characteristics}

After the use of immunohistochemistry to assess the expression of chromogranin A, synaptophysin, and $\mathrm{Ki} 67$ to assess the neuroendocrine differentiation, sixtytwo samples $(88.6 \%)$ were diagnosed with high-grade colorectal adenocarcinoma, and 8 (11.4\%) were NEN from the total 70 samples.

Table 1 describes the clinical parameter associated with NENs.

Of the 8 patients diagnosed with NEN, $63 \%$ were male and $37 \%$ were female. Regarding age distribution, $63 \%$ were 50 years old and older and $37 \%$ were younger than 50 years old. The most common symptom (about 62.5\%) was bloody stools. Other symptoms include a lump in the stomach, intestinal disorders, weight loss, abdominal pain, nausea, vomiting, and pain in the anus - about $12.5 \%$ for each symptom. Based on the tumor's location, the majority of neuroendocrine neoplasms were found in the rectum, about $75 \%$ and only $25 \%$ were in the transverse colon area. All of the tumor sizes were $>2 \mathrm{~cm}$ in size, with the largest size $10 \times 8 \mathrm{~cm}$ and the smallest $3 \times 2 \mathrm{~cm}$. The most common tumor growth patterns found were glandular and undifferentiated patterns - about $37.5 \%$ 
Table 1: Clinical characteristics of the eight cases of neuroendocrine neoplasms found in the study

\begin{tabular}{|c|c|c|}
\hline Clinical characteristics & $\mathrm{n}=8$ & $\%$ \\
\hline \multicolumn{3}{|l|}{ Gender } \\
\hline Males & 5 & 63 \\
\hline Females & 3 & 37 \\
\hline \multicolumn{3}{|l|}{ Age (years) } \\
\hline$\geq 50$ & 5 & 63 \\
\hline$<50$ & 3 & 37 \\
\hline \multicolumn{3}{|l|}{ Clinical Symptoms } \\
\hline Bloody stool & 5 & 62.5 \\
\hline Lump in stomach & 1 & 12.5 \\
\hline $\begin{array}{l}\text { Defecation disorders, weight loss, abdominal pain, nausea and } \\
\text { vomiting }\end{array}$ & 1 & 12.5 \\
\hline Pain at the anus & 1 & 12.5 \\
\hline \multicolumn{3}{|l|}{ Location } \\
\hline Rectum & 6 & 75 \\
\hline Transverse colon & 2 & 25 \\
\hline \multicolumn{3}{|l|}{ Tumor Size $(\mathrm{cm})$} \\
\hline$<2$ & 0 & 0 \\
\hline$>2$ & 8 & 100 \\
\hline \multicolumn{3}{|l|}{ Growth Pattern } \\
\hline Glandular & 3 & 37.5 \\
\hline Undifferentiated & 3 & 37.5 \\
\hline Insular & 1 & 12.5 \\
\hline Trabecular & 1 & 12.5 \\
\hline \multicolumn{3}{|l|}{ Cytomorphological Pattern } \\
\hline Large Cell & 5 & 62.5 \\
\hline Classic & 2 & 25 \\
\hline Non-classic & 1 & 12.5 \\
\hline \multicolumn{3}{|l|}{ Diagnosis } \\
\hline NET G1 & 1 & 12.5 \\
\hline NET G2 & 1 & 12.5 \\
\hline NET G3 & 1 & 12.5 \\
\hline LCNEC & 5 & 62.5 \\
\hline
\end{tabular}

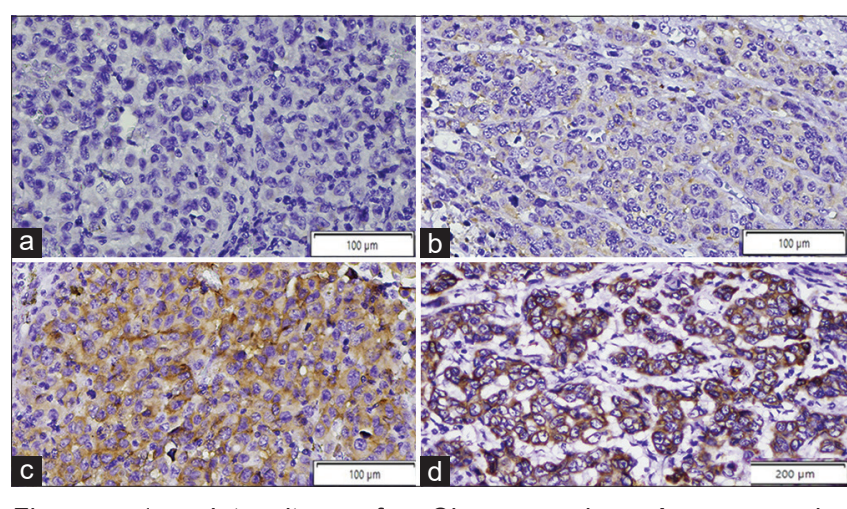

Figure 1: Intensity of Chromogranin $A$ expression immunohistochemically. (a) Negative (0 point), (b) Weak (1 point), (c) Intermediate (2 point), (d) Strong staining (3 point) (Obj. ×40)

for each pattern, then insular and trabecular patterns - about $12.5 \%$ for each pattern. The most frequent cytomorphological features were NEN with large cell nuclei with $62.5 \%$, followed by classical nuclei with $25.0 \%$, and non-classical nuclei with $12.5 \%$.

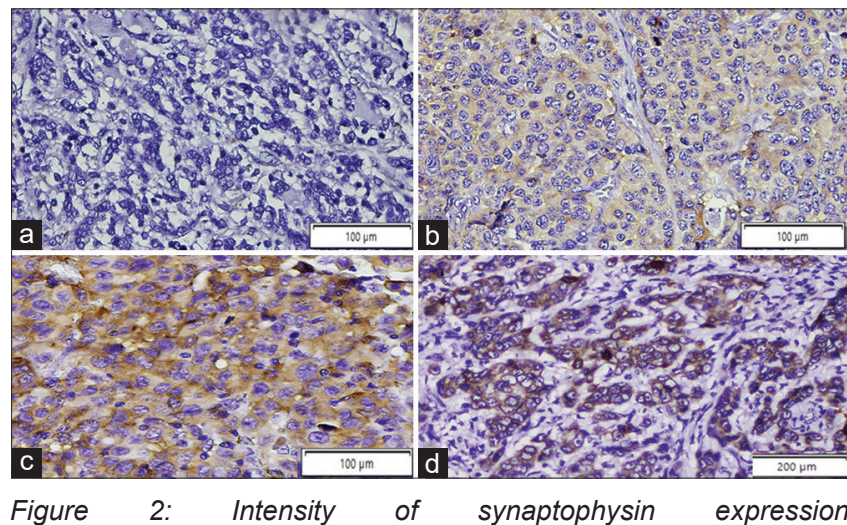

Figure 2: Intensity of synaptophysin expression immunohistochemically. (a) Negative (0 point), (b) Weak (1 point), (c) Intermediate (2 point), (d) Strong staining (3 point) (Obj. ×40)

\section{IHC analysis of chromogranin A,} synaptophysin and Ki67

Figures 1 and 2 show the intensity of chromogranin A and synaptophysin expression as they stained brown in the cytoplasm of tumor cells. The intensity was categorized in negative, weak, intermediate and strong staining with 0-3 point. Meanwhile, Figures 3 and 4 show the positivity of chromogranin $A$ and synaptophysin expression in NEN. Figure 5 show the expression of Ki67 in a sample of neuroendocrine neoplasms. The growth pattern and the cytomorphology of tumor cells in the neuroendocrine neoplasm samples with Hematoxylin Eosin staining is shown in Figures 6 and 7.

The Ki67 proliferation index value is determined by counting at least 500 cells in the regions of the highest labeling (hot-spot) which are identified at scanning/ microscope magnification [5].

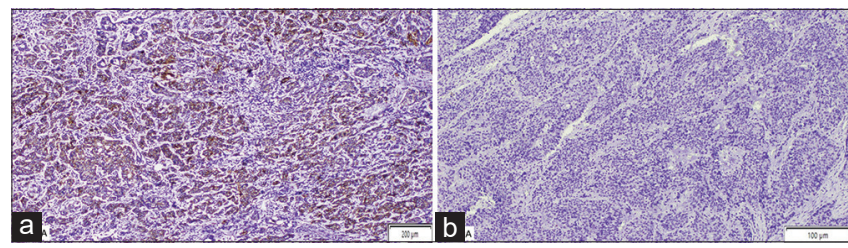

Figure 3: Expression of chromogranin A immunohistochemically (Obj. ×40) (a) Positive (b) Negative

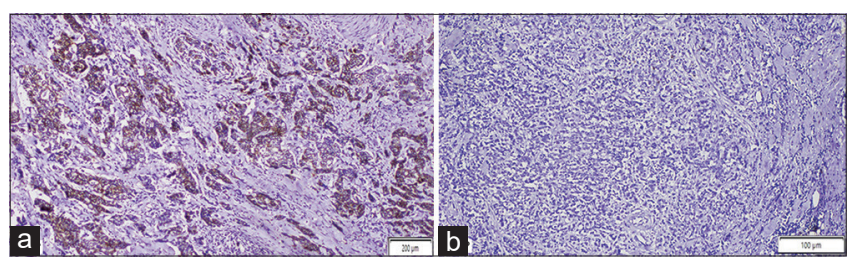

Figure 4: Expression of synaptophysin immunohistochemically (Obj. ×40) (a) Positive (b) Negative

From the results of this study, all cases of NEN showed positive expression for chromogranin A, synaptophysin and Ki67. Six from eight $(75 \%)$ of the samples diagnosed with NEN were high-grade tumors and the rest were low and intermediate tumors. The grading of the tumors was based on the mitosis and Ki67 criteria that were shown in Table 2. The high-grade tumor also have higher mitotic activity $(>20)$ compared to the low grade tumor $(<20)$. Table 3 shows the classification and grading of neuroendocrine neoplasms that associated with the sample characteristics.

\section{Discussion}

The data on the characteristics of the sample showed that the incidence of NEN was most common in males, especially in the diagnosis of LCNEC with a median age of 51 years. This study is in accordance with previous studies that the incidence of NEN in the gastrointestinal tract is more common in males than females [15]. NEN most often occurs at the age of 


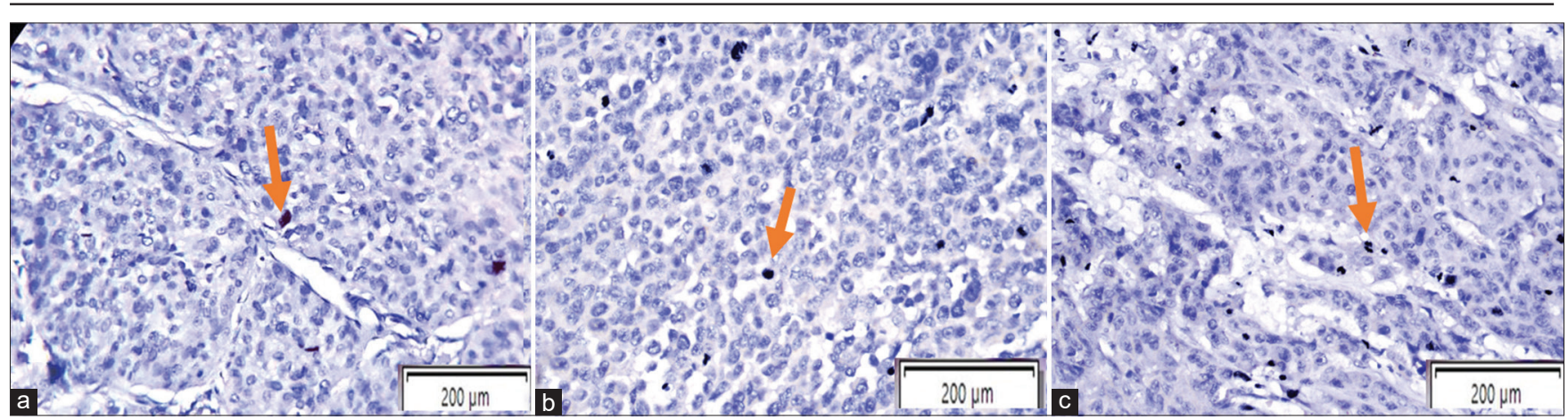

Figure 5: Percentage of Ki67 expression immunohistochemistically (Obj. ×40) (a) Ki67 <3\% (b) Ki67 3-20\% (c) Ki67 >20\%. Arrow: Positively stained

50 years which is also the most common in LCNEC diagnoses; this is in accordance with the statement that the incidence of NEN often occurs in the fifth to the seventh decade due to the non-progressive nature of NET growth so that after it enlarges and causes atypical symptoms, cases are often diagnosed when patients are over 50 years old [16].

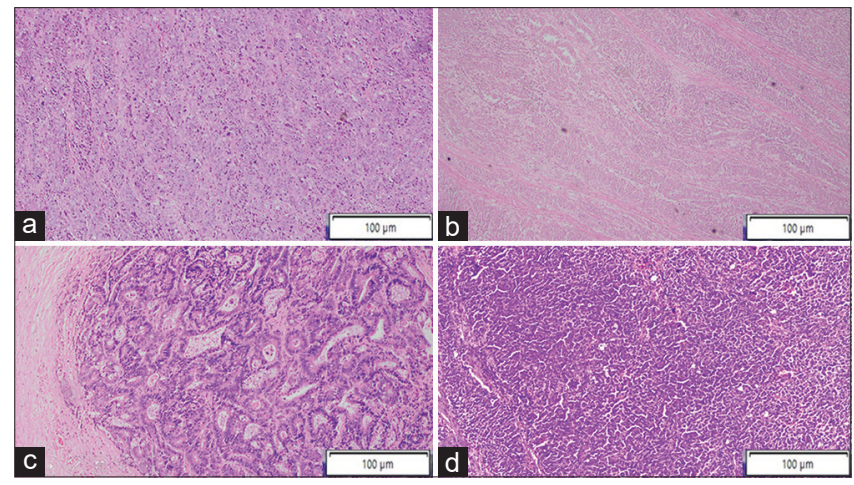

Figure 6: Growth pattern of NEN. (a) Insular, (b) Trabecular, (c) Glandular, (d) Undifferentiated (H\&E stain, Obj. ×10)

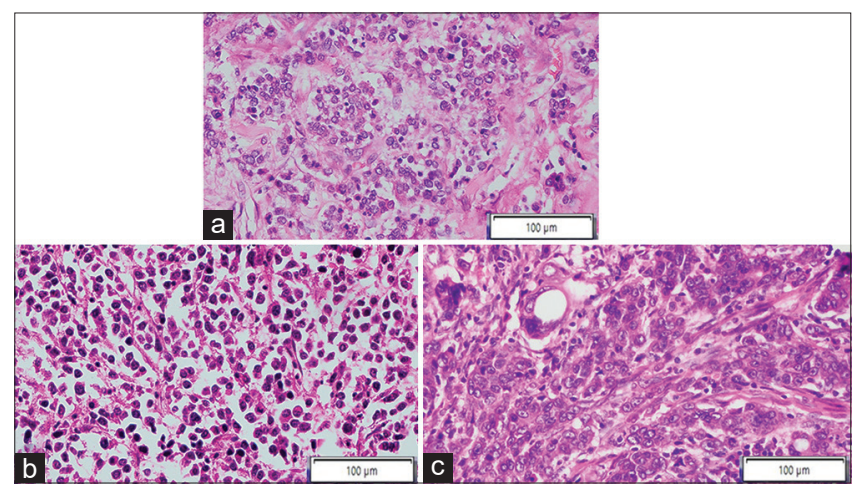

Figure 7: Cytomorphology of NEN. (a) Classic, (b) Non-classic, (c) Large cell (H\&E stain, Obj. $\times 40)$

Based on clinical symptoms, the most frequent symptom was bloody stools that were usually found in LCNEC followed by a lump in the abdomen, bowel obstruction, weight loss, abdominal pain, nausea and vomiting and rectal pain. These symptoms are associated with non-functional neuroendocrine tumors that are not caused by hormones but due to the tumor progression. Bloody stool and painful bowel movements are usually the results of mechanical trauma associated with the passage of solid feces over the tumor surface. The indolent nature of NET causes many patients to be asymptomatic in the early stages or present with only vague symptoms and the most common symptoms are abdominal pain, weight loss, as well as gastrointestinal obstruction such as constipation and bloody stools [16], [17], [12].

The location of the tumor in this study indicated that the rectum was the most frequent site of LCNEC followed by the transverse colon. Colorectal cancer mainly occurs on the left side of rectum [5]. NEN was found more often in the rectum (94.5\%) than in the colon $(3.9 \%)$ and appendix (1.6\%) [18]. All tumor sizes in this study were $>2 \mathrm{~cm}$ surgically obtained. These results are in contrast to previous studies where NEN tumors in the rectum were smaller and usually detected as small submucosal polypoid nodules on endoscopy. More than half were $<1.0 \mathrm{~cm}$ in diameter, and only about $7 \%$ were $>2 \mathrm{~cm}$. The size of the NEN tumor mass in the large intestine was larger than in the small intestine, appendix, and rectum, with a reported average size of $4.9 \mathrm{~cm}$ [5]. In addition, other studies have also shown that the symptoms of colorectal NEN are non-specific so that clinically patients experience delays in diagnosis and are often misdiagnosed, which results in patients presenting with tumors that are $>2 \mathrm{~cm}$ in size with advanced stages even metastases [19], [20], [21].

The most common pattern in NEN diagnosis in this study was the glandular pattern and the undifferentiated pattern with a large cell type nucleus that was difficult to distinguish from adenocarcinoma by relying solely on HE staining. According to Takizawa, NEN can have a morphological picture similar to highgrade adenocarcinoma because both originate from the epithelium and the location is also the same, namely colorectal. It is suspected that they have the same genetic mutation, namely in RB1, TP53, APC, KRAS, PIK3CA, BRAF [8], [22], so that immunohistochemical examination with neuroendocrine markers is very important and crucial to establishthe diagnosis.

After performing an immunohistochemical analysis to differentiate from adenocarcinoma, the diagnosis of NEN was obtained, with the most growth patterns being glandular and undifferentiated patterns. Glandular growth patterns were found in 
Table 2: Diagnosis and grading of neuroendocrine neoplasms

\begin{tabular}{|c|c|c|c|c|c|c|}
\hline No & Chromogranin A & Synaptophysin & Mitosis (/10LPB) & Ki67 (\%) & Diagnosis & Grading \\
\hline 1 & Positive & Positive & $<2$ & $<3$ & NET G1 & Low \\
\hline 2 & Positive & Positive & $>20$ & $>20$ & LCNEC & High \\
\hline 3 & Positive & Positive & $>20$ & $>20$ & LCNEC & High \\
\hline 4 & Positive & Positive & $>20$ & $>20$ & NET G3 & High \\
\hline 5 & Positive & Positive & $>20$ & $>20$ & LCNEC & High \\
\hline 6 & Positive & Positive & $>20$ & $>20$ & LCNEC & High \\
\hline 7 & Positive & Positive & $>20$ & $>20$ & LCNEC & High \\
\hline 8 & Positive & Positive & $2-20$ & $3-20$ & NET G2 & Intermediate \\
\hline
\end{tabular}

Table 3: Classification and grading of neuroendocrine neoplasms associated with the sample characteristics (gender, age, clinical symptoms and location)

\begin{tabular}{|c|c|c|c|c|c|c|c|c|c|c|}
\hline \multirow[t]{2}{*}{ Diagnosis } & \multicolumn{2}{|c|}{ Gender } & \multicolumn{2}{|l|}{ Age } & \multicolumn{4}{|c|}{ Clinical Symptoms } & \multicolumn{2}{|l|}{ Location } \\
\hline & Males & Females & $\begin{array}{l}<50 \\
\text { years } \\
\text { old }\end{array}$ & $\begin{array}{l}\geq 50 \\
\text { years } \\
\text { old }\end{array}$ & $\begin{array}{l}\text { Lump in } \\
\text { stomach }\end{array}$ & $\begin{array}{l}\text { Bloody } \\
\text { stool }\end{array}$ & $\begin{array}{l}\text { Defecation disorders, weight } \\
\text { loss, abdominal pain, nausea } \\
\text { and vomiting }\end{array}$ & $\begin{array}{l}\text { Pain at } \\
\text { the anus }\end{array}$ & $\begin{array}{l}\text { Transverse } \\
\text { colon }\end{array}$ & Rectum \\
\hline NET G1 & 1 & 0 & 0 & 1 & 0 & 0 & 0 & 1 & 0 & 1 \\
\hline \multirow[t]{2}{*}{ NET G2 } & 1 & 0 & 0 & 1 & 1 & 0 & 0 & 0 & 0 & 1 \\
\hline & $20 \%$ & $0 \%$ & $0 \%$ & $20 \%$ & $100 \%$ & $0 \%$ & $0 \%$ & $0 \%$ & $0 \%$ & $16.7 \%$ \\
\hline \multirow[t]{2}{*}{ NET G3 } & 1 & 0 & 0 & 1 & 0 & 1 & 0 & 0 & 0 & 1 \\
\hline & $20 \%$ & $0 \%$ & $0 \%$ & $20 \%$ & $0 \%$ & $20 \%$ & $0 \%$ & $0 \%$ & $0 \%$ & $16.7 \%$ \\
\hline \multirow[t]{2}{*}{ LCNEC } & 2 & 3 & 3 & 2 & 0 & 4 & 1 & 0 & 2 & 3 \\
\hline & $40 \%$ & $100 \%$ & $100 \%$ & $40 \%$ & $0 \%$ & $80 \%$ & $100 \%$ & $0 \%$ & $100 \%$ & $50.0 \%$ \\
\hline \multirow[t]{2}{*}{ Total } & 5 & 3 & 3 & 5 & 1 & 5 & 1 & 1 & 2 & 6 \\
\hline & $100 \%$ & $100 \%$ & $100 \%$ & $100 \%$ & $100 \%$ & $100 \%$ & $100 \%$ & $100 \%$ & $100 \%$ & $100 \%$ \\
\hline
\end{tabular}

Table 4: Classification and grading of neuroendocrine neoplasms associated with the sample characteristics (tumor size, growth pattern, and cytomorphological)

\begin{tabular}{|c|c|c|c|c|c|c|c|c|c|c|}
\hline \multirow[t]{2}{*}{ Diagnosis } & \multicolumn{3}{|c|}{ Tumor size } & \multicolumn{4}{|c|}{ Growth Pattern } & \multicolumn{3}{|c|}{ Cytomorphological } \\
\hline & $<1 \mathrm{~cm}$ & $1-2 \mathrm{~cm}$ & $>2 \mathrm{~cm}$ & Insular & Trabecular & Glandular & Undifferentiated & Classic & Non classic & Large cell \\
\hline \multirow[t]{2}{*}{ NET G1) } & 0 & 0 & 1 & 1 & 0 & 0 & 0 & 0 & 1 & 0 \\
\hline & $0 \%$ & $0 \%$ & $12.5 \%$ & $100 \%$ & $0 \%$ & $0 \%$ & $0 \%$ & $0 \%$ & $100 \%$ & $0 \%$ \\
\hline \multirow[t]{2}{*}{ NET G2 } & 0 & 0 & 1 & 0 & 0 & 0 & 1 & 1 & 0 & 0 \\
\hline & $0 \%$ & $0 \%$ & $12.5 \%$ & $0 \%$ & $0 \%$ & $0 \%$ & $33.3 \%$ & $50 \%$ & $0 \%$ & $0 \%$ \\
\hline \multirow[t]{2}{*}{ NET G3 } & 0 & 0 & 1 & 0 & 0 & 1 & 0 & 1 & 0 & 0 \\
\hline & $0 \%$ & $0 \%$ & $12.5 \%$ & $0 \%$ & $0 \%$ & $33.3 \%$ & $0 \%$ & $50 \%$ & $0 \%$ & $0 \%$ \\
\hline \multirow[t]{2}{*}{ LCNEC } & 0 & 0 & 5 & 0 & 1 & 2 & 2 & 0 & 0 & 5 \\
\hline & $0 \%$ & $0 \%$ & $62.5 \%$ & $0 \%$ & $100 \%$ & $66.7 \%$ & $66.7 \%$ & $0 \%$ & $0 \%$ & $100 \%$ \\
\hline \multirow[t]{2}{*}{ Total } & 0 & 0 & 8 & 1 & 1 & 3 & 3 & 2 & 1 & 5 \\
\hline & $0 \%$ & $0 \%$ & $100 \%$ & $100 \%$ & $100 \%$ & $100 \%$ & $100 \%$ & $100 \%$ & $100 \%$ & $100 \%$ \\
\hline
\end{tabular}

NET G3 and LCNEC. Undifferentiated patterns were found in NETs G2 and LCNEC, whereas insular and trabecular patterns were found only in NETs G1 and LCNECs, respectively. In tumor cytomorphology, the most common cytomorphology was the large cell type nucleus, followed by classical and non-classical nuclei. The results of this study are in line with the pattern of tumor growth and tumor cytomorphology which are often found wherein LCNEC cytomorphology, tumor cells were seen with a round nucleus, moderatesevere pleomorphism, large size, real nucleus, and relatively large cytoplasm, while in classical NET cytomorphology, the picture shows tumor cells with round nuclei, relatively small size, monotonous shape with salt and pepper chromatin and eosinophilic cytoplasm. Non-classical nuclear cytomorphology provides an overview of tumor cells that can be spindlenucleated and bizarre [12], [5]. Table 2 shows that $75 \%$ of the samples diagnosed with NEN were high-grade tumors, namely NET G3 and LCNEC; the rest were NET G1 and NET G2. This classification was made based on the Ki67 index and the number of mitoses in the histological material. Ki67 is one factor that influences the prognosis of the disease [10]. This is in accordance with the study that of the eight (8) samples, histopathologically NEN was a G3 NET, and NEC was a high-grade malignant tumor characterized by all samples positive immunoexpression at Ki-67 >20\%.

Based on the research that has been conducted in this study during the $2015-2019$ period, from a total of 70 samples of high-grade colorectal adenocarcinoma, 8 cases $(11.4 \%)$ were neuroendocrine neoplasms with a classification of 1 sample (1.4\%) each of NET G1, NET G2, NET G3 and five (5) samples (7.1\%) of LCNEC which can be seen in Table 1. The data obtained are in accordance with a previous study by Stewart in the United States [23] where the diagnosis of high-grade colorectal adenocarcinoma is not always pure as highgrade adenocarcinoma because it may be a NEN.

As a conclusion, the final diagnosis obtained from 8 samples diagnosed as NEN were NET G1, G2, and G3, with a percentage of $1.4 \%$ respectively and LCNEC with $7.1 \%$ based on chromogranin $A$, synaptophysin and Ki67 specific neuroendocrine markers.

\section{References}

1. Yusuf I, Pardamean B, Baurley JW, Budiarto A, Miskad UA, Lusikooy RE, et al. Genetic risk factors for colorectal cancer in 
multiethnic Indonesians. Sci Rep. 2021;11(1):1-9. https://doi. org/10.1038/s41598-021-88805-4

2. Kyriakopoulos G, Mavroeidi V, Chatzellis E, Kaltsas GA, Alexandraki KI. Histopathological, immunohistochemical, genetic and molecular markers of neuroendocrine neoplasms. Ann Transl Med. 2018;6(12):252-2. https://doi.org/10.21037/ atm.2018.06.27

PMid:30069454

3. Herrera-Martínez AD, Hofland LJ, Gálvez Moreno MA, Castaño JP, De Herder WW, Feelders RA. Neuroendocrine neoplasms: Current and potential diagnostic, predictive and prognostic markers. Endocr Relat Cancer. 2019;26(3):R157-79. https://doi.org/10.1530/Erc-18-0354

PMid:30615596

4. Bruera G, Giuliani A, Romano L, Chiominto A, Di Sibio A, Mastropietro S, et al. Poorly differentiated neuroendocrine rectal carcinoma with uncommon immune-histochemical features and clinical presentation with a subcutaneous metastasis, treated with first line intensive triplet chemotherapy plus bevacizumab FIr-B/FOx regimen: An exper. BMC Cancer. 2019;19(1):960. https://doi.org/10.1186/s12885-019-6214-z

PMid:31619203

5. Rindi G, Komminoth P, Scoazec JY. olorectal neuroendocrine neoplasm. In: Nagtegaal ID, Arends MJ, Odze RD, editors. WHO Classification of Tumours Digestive System Tumours. $5^{\text {th }}$ ed. Lyon: World Health Organization; 2019. p. 188-91.

6. Miskad UA, Hamzah N, Cangara MH, Nelwan BJ, Masadah R, Wahid S. Programmed death-ligand 1 expression and tumorinfiltrating lymphocytes in colorectal adenocarcinoma. Minerva Med. 2020;111(4):337-43. https://doi.org/10.23736/ S0026-4806.20.06401-0

PMid:33032394

7. Chen $\mathrm{Y}$, Liu F, Meng Q, Ma S. Is neuroendocrine differentiation a prognostic factor in poorly differentiated colorectal cancer? World J Surg Oncol. 2017;15(1):4-9. https://doi.org/10.1186/ s12957-017-1139-y

PMid:28351413

8. Kim JJ, Park SS, Lee TG, Lee HC, Lee SJ. Large cell neuroendocrine carcinoma of the colon with carcinomatosis peritonei. Ann Coloproctol. 2018;34(4):222-5. https://doi. org/10.3393/ac.2018.02.27

PMid:30048995

9. Duan K, Mete O. Algorithmic approach to neuroendocrine tumors in targeted biopsies: Practical applications of immunohistochemical markers. Cancer Cytopathol. 2016;124(12):871-84. https://doi.org/10.1002/cncy.21765 PMid:27529763

10. Oberg K, Couvelard A, Delle Fave G, Gross D, Grossman A, Jensen RT, et al. ENETS consensus guidelines for the standards of care in neuroendocrine tumors: Biochemical markers. Neuroendocrinology. 2017;105(3):201-11. https://doi. org/10.1159/000472254 PMid:28391265

11. Marotta V, Zatelli MC, Sciammarella C, Ambrosio MR, Bondanelli M, Colao A, et al. Chromogranin a as circulating marker for diagnosis and management of neuroendocrine neoplasms: More flaws than fame. Endocr Relat Cancer.
2018;25(1):R11-29. https://doi.org/10.1530/ERC-17-0269 PMid:29066503

12. Miskad UA, Krisnuhoni E, Handjari DR, Rahadiani N Stephanie M. Gastroenteropancreatic neuroendocrine tumor (GEPNET): Perspektif penegakan diagnosis patologi anatomie. In: Rahadiani N, editor. Gastroenteropancreatic Neuroendocrine Tumor (GEPNET): Perspektif Penegakan Diagnosis Patologi Anatomi. Jakarta: (IAPI), Perhimpunan Dokter Spesialis Patologi anatomi; 2019. p. 1-57.

13. Feldman AT, Wolfe D. Tissue processing and hematoxylin and eosin staining. Methods Mol Biol. 2014;1180:31-43. https://doi. org/10.1007/978-1-4939-1050-2_3

PMid:25015141

14. Bratthauer $\mathrm{GL}$. The avidin-biotin complex (ABC) method and other avidin-biotin bindingmethods. Methods MolBiol.2010;588:257-70. https://doi.org/10.1007/978-1-59745-324-0_26 PMid:20012837

15. Mahayasa M, Wibowo PS. Tumor neuroendokrin: Kasus serial di RSUD Dr. Soetomo. JBN. 2018;2(1):28. https://doi. org/10.24843/JBN.2018.v02.i01.p05

16. Amber Cockburn TAR. Gastrointestinal Neuroendocrine Lesions. In: Noffsinger A, editor. Fenoglio-Preiser's Gastrointestinal Pathology. $4^{\text {th }}$ ed. Philadelphia, PA: Wolters Kluwer; 2017. p. 3354-433.

17. Amoruso M, Papagni V, Picciariello A, Pinto VL, Abbicco DD, Margari A. CASE REPORT-OPEN ACCESS international journal of surgery case reports intestinal occlusion by stenotic neuroendocrine tumours of left colon and concomitant association with small bowel gastrointestinal stromal tumours: A case report. Int J Surg Case Rep. 2018;53:182-5. https://doi. org/10.1016/j.ijscr.2018.10.034

18. Kojima M, Ikeda K, Saito N, Sakuyama N, Koushi K, Kawano S, et al. Neuroendocrine tumors of the large intestine: Clinicopathological features and predictive factors of lymph node metastasis. Front Oncol. 2016;6:173. https://doi.org/10.3389/ fonc. 2016.0017 PMid:27486567

19. Al-Risi ES, Al-Essry FS, Mula-Abed WA. Chromogranin A as a biochemical marker for neuroendocrine tumors: A single center experience at Royal Hospital, Oman. Oman Med J. 2017;32(5):365-70. https://doi.org/10.5001/omj.2017.71

20. Gut P, Czarnywojtek A, Fischbach J, Baczyk M, Ziemnicka K, Wrotkowska E, et al. Chromogranin A-unspecific neuroendocrine marker. Clinical utility and potential diagnostic pitfalls. Arch Med Sci. 2016;12(1):1-9. https://doi.org/10.5114/aoms.2016.57577

21. Crabtree JS, Miele L. Neuroendocrine tumors: Current therapies, notch signaling, and cancer stem cells. J Cancer Metastasis Treat. 2016;2(8):279. https://doi.org/10.20517/2394-4722.2016.30

22. Lee SM, Sung CO. Comprehensive analysis of mutational and clinicopathologic characteristics of poorly differentiated colorectal neuroendocrine carcinomas. Sci Rep. 2021;11(1):1-11. https:// doi.org/10.1038/s41598-021-85593-9

23. Stewart SL, Wike JM, Kato I, Lewis DR, Michaud F. A populationbased study of colorectal cancer histology in the United States, 1998-2001. Cancer. 2006;107 Suppl 1:1128-41. https://doi. org/10.1002/cncr.22010

PMid: 16802325 